\title{
The Cradle of Humankind \\ Evolutionary Approaches to Technology and Parenting
}

\section{Geoff Kushnick ${ }^{1}$}

School of Archaeology and Anthropology, The Australian National University

Published Version: Kushnick G (2021). The cradle of humankind: evolutionary approaches to technology and parenting. In: Weekes-Shackelford VA, Shackelford TK (eds.), The Oxford Handbook of Evolutionary Psychology and Parenting (pp. 115-134). Oxford University Press. https://doi.org/10.1093/oxfordhb/9780190674687.013.25

\section{INTRODUCTION}

In the 1990s, infant-centered television—typified by TV and DVD series such as 'Baby Einstein'—was all the craze among Western parents. Its popularity could be attributed to a number of factors, including (a) the marketing efforts of large companies, (b) the belief that it boosted children's intelligence and the inculcation of hard-to-learn skills (Christakis 2009), and (c) that it provided a means for parents to safely 'park' their children while freeing hands for other important obligations. Although this example sits in recent enough memory to be salient, it is not the only example of technology shaping the way we parent. Technology has always been an important driver of offspring-directed parental beliefs and behaviour, and vice versa (some examples are illustrated in Figure 1). Although technology is thought to be what separates us from our animal roots, the theory that explains our oneness with the animal kingdom-evolutionary theory—is poised to illuminate our understanding of the relationship between parenting and technology.
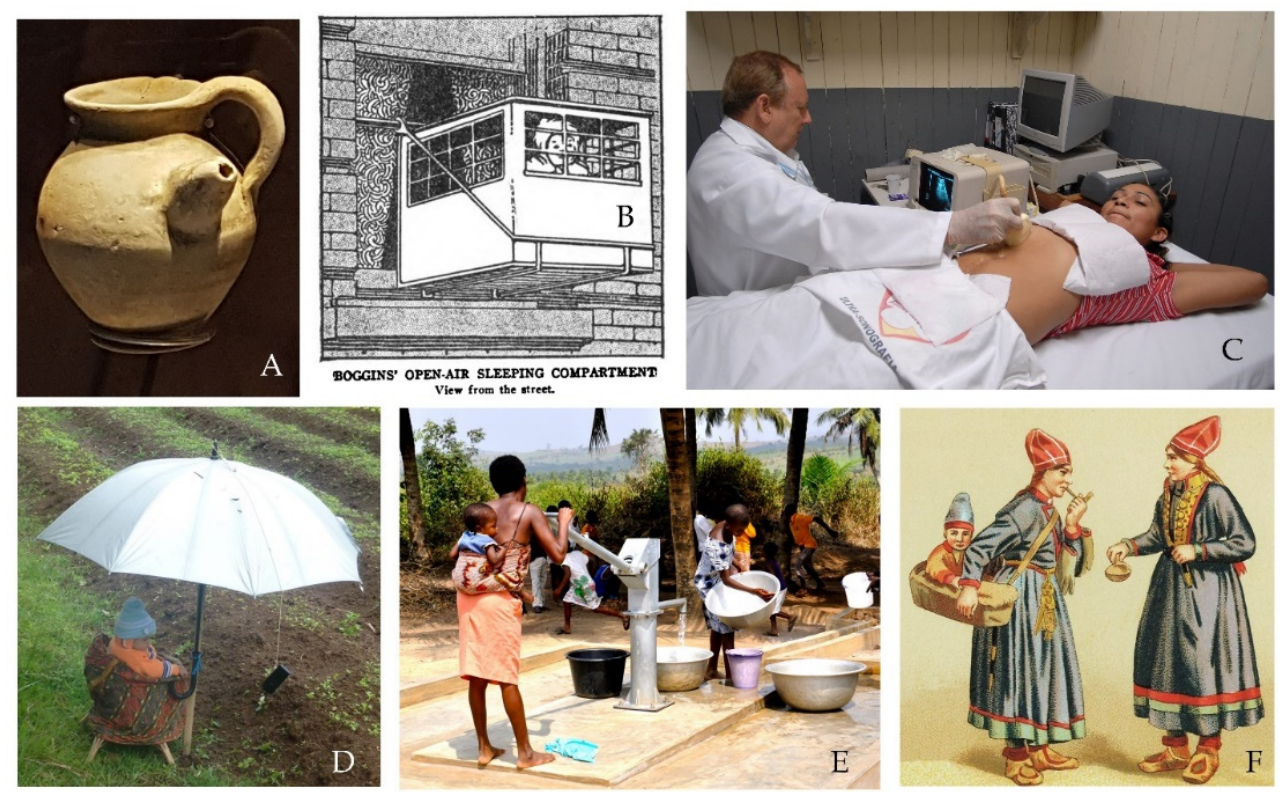

FIGURE 1. Technology as always been an important driver of offspring-directed parental behaviour and beliefs, and vice versa. Pictured here are some examples: (A) terracotta infant-feeding vessel from southern Italy (4 ${ }^{\text {th }}$ Century BC); (B) advertisement for a baby cage used to get fresh air for children in crowded cities (early $20^{\text {th }}$ century); (C) woman getting a fetal ultrasound in a rural clinic in Brazil; (D) ingenious contraption used by a Karo mother in rural Indonesia to keep a baby safe and occupied with a chair, umbrella, and mobile phone while she tends to a tomato garden; (E) woman with her baby slung on her back using a water pump in Ghana; and, (F) Sami woman carrying a child in a Komse, or child carrier, in Lapland, Sweden (ca. 1880). Copyright information for images: (A) photograph taken by author from ANU Classics Museum, Canberra; (B) public domain image taken from Fischer (1905); (C) Agencia de Noticias do Acre, Creative Common CC BY 2.0; (D) photograph taken by author; (E) USAID, public domain; and, (F) public domain image from 1880.

\footnotetext{
${ }^{1}$ Contact: geoff.kushnick@anu.edu.au
} 
In this chapter, I will explore the relationship between parenting and technology in evolutionary perspective. The exploration is organized around Smith's (2000) 'three styles' framework for understanding and differentiating between the three major evolutionary approaches to the study of human behaviour: evolutionary psychology, human behavioural ecology, and dual inheritance theory. For each of these three approaches, I will provide a brief outline of the theory and how it is relevant for understanding parental behaviour, and provide examples of how each approach has illuminated (in the case of well documented examples) or might illuminate (in the case of more speculative examples) our understanding of the relationship between parenting and technology.

Throughout the chapter, 'parenting' refers to all classes of potential contributions to parental effort and, accordingly, I have chosen examples to show the relevance of this approach to both childbearing and childrearing behaviour - that is, behaviour related to both having children and taking care of them. According to the 'Oxford Living Dictionary', technology derives from the Greek tekhne ('art, craft') and logia, and is defined as "the application of scientific knowledge for practical purposes; machinery and equipment developed from the application of scientific knowledge" (Oxford Living Dictionary 2017). Whereas technology usually is thought to apply to systems of production, here I will focus on its effects on reproduction.

Although the chapter explores the breadth of scholarship on the evolution of human behaviour, I have made no attempt to provide a comprehensive account of evolutionary perspectives on human behavior, in general, or the relationship between parenting and technology, more specifically. I have also focused only on neo-Darwinian evolutionary approaches, though I recognize that there are other ways to look at the relationship between human behaviour and technology from an evolutionary perspective, including in my own discipline of anthropology (e.g., White 1959). The other chapters in this volume provide the depth that I cannot. My goal with this chapter is simply to show that evolutionary approaches are useful for understanding the relationship between technology and parenting, and that each of the three approaches brings unique insights. I also have not tried to provide an account of the evolutionary history of the relationship between parenting and technology. You will thus not find timelines for the emergence of various parenting-related technology. Finally, although evolution is often conceived of as an approach that privileges the past, I hope to show how an evolutionary perspective can (or cannot) shed light on the future.

\section{Parenting and Technology in Evolutionary Perspective}

The 'three styles' framework was developed by Smith (2000) to outline the differences in key assumptions between the three main evolutionary approaches to the study of human behavior: evolutionary psychology, human behavioural ecology, and dual inheritance theory (which I will refer to as EP, HBE, and DIT from here forward). It is a useful starting point for the exploration of the relationship between parenting and technology from an evolutionary perspective because it recognizes differences between the approaches that will help explain and elucidate different examples of the relationship. Despite these differences, which are outlined in Table 1, in accord with other scholars attempting to tackle this diversity (Blurton Jones 1990; Daly and Wilson 1999; Laland and Brown 2011), the framework identifies much complementarity among the approaches and calls for integration.

For each of the evolutionary approaches, I have chosen two examples to illustrate the relationship between technology and parenting. For many of the examples, more than one of the three approaches could provide unique insights (the aforementioned complementarity). Where this is the case, I have provided some brief notes. In all cases, I have provided some bibliographic notes in case the reader would like to explore the example, or the approach in general, in more detail.

\subsection{Evolutionary Psychology}

Evolutionary psychology (EP) has as its focus psychological mechanisms, and attempts to explain these mechanisms as the product of natural selection. The brain is viewed as being composed of many of these mechanisms, each evolved to solve a specific problem in the environment of evolutionary adaptedness. Because evolutionary change takes place over long periods of time, human adaptation is somewhat inflexible especially in the face of rapidly changing environments. Maladaptive behaviour caused by adaptive lag is thus viewed in EP as the norm rather than the exception. For that reason, evolutionarily novel technology related to parenting is likely to lead to behaviour that fails to maximize fitness (i.e., leads to lower than the maximal number of gene copies passed on to future generations). Adaptive behaviour will only result from technology that is not evolutionarily novel, or technology that can tap into existing mechanisms (that evolved for other purposes) in adaptive ways. 
TABLE 1. The 'three styles' framework (adapted from Smith 2000: 34).

\begin{tabular}{|c|c|c|c|}
\hline & $\begin{array}{l}\text { Evolutionary Psychology } \\
\text { (EP) }\end{array}$ & $\begin{array}{l}\text { Human Behavioural } \\
\text { Ecology (HBE) }\end{array}$ & $\begin{array}{l}\text { Dual Inheritance Theory } \\
\text { (DIT) }\end{array}$ \\
\hline Explanandum: & Psychological mechanisms & Behavioural strategies & Cultural evolution \\
\hline Key constraints: & Cognitive, genetic & Ecological, material & Structural, information \\
\hline $\begin{array}{l}\text { Temporal scale } \\
\text { of adaptive } \\
\text { change: }\end{array}$ & Long-term (genetic) & Short-term (phenotypic) & Medium-term (cultural) \\
\hline $\begin{array}{l}\text { Expected current } \\
\text { adaptiveness: }\end{array}$ & Lowest & Highest & Intermediate \\
\hline $\begin{array}{l}\text { Relationship } \\
\text { between } \\
\text { technology and } \\
\text { parenting: }\end{array}$ & $\begin{array}{l}\text { The degree to which } \\
\text { parenting technologies are } \\
\text { evolutionarily novel predicts } \\
\text { whether we will interact } \\
\text { with them in adaptive or } \\
\text { maladaptive ways }\end{array}$ & $\begin{array}{l}\text { Technologies, like other } \\
\text { aspects of the social and } \\
\text { physical environment, alter } \\
\text { the fitness costs and } \\
\text { benefits of parental care; } \\
\text { parental behaviour altered } \\
\text { to optimize balance of costs } \\
\text { and benefits of care }\end{array}$ & $\begin{array}{l}\text { Parenting-related } \\
\text { technologies adopted } \\
\text { and/or modified because of } \\
\text { survival value (adaptive) or } \\
\text { other biases in cultural } \\
\text { transmission (potentially } \\
\text { maladaptive) }\end{array}$ \\
\hline $\begin{array}{l}\text { Childbearing } \\
\text { example: }\end{array}$ & $\begin{array}{l}\text { Contraceptive technology } \\
\text { leads to the decoupling of } \\
\text { cultural and reproductive } \\
\text { success }\end{array}$ & $\begin{array}{l}\text { Labour-saving technology } \\
\text { alters the costs of maternal } \\
\text { activities leading to } \\
\text { potential increases in } \\
\text { fertility }\end{array}$ & $\begin{array}{l}\text { Soap operas lead to the } \\
\text { cultural transmission of } \\
\text { family planning knowledge } \\
\text { and norms for decreased } \\
\text { fertility }\end{array}$ \\
\hline $\begin{array}{l}\text { Childrearing } \\
\text { example: }\end{array}$ & $\begin{array}{l}\text { Ultrasounds allow for } \\
\text { prenatal sex determination } \\
\text { and, when coupled with } \\
\text { strong son preference and } \\
\text { the one-child policy, have } \\
\text { contributed to the 'Missing } \\
\text { Girls' phenomenon in } \\
\text { China }\end{array}$ & $\begin{array}{l}\text { Infant-carrying devices } \\
\text { allow for women to } \\
\text { simultaneously engage in } \\
\text { childcare and subsistence } \\
\text { work }\end{array}$ & $\begin{array}{l}\text { Cultural evolution of infant- } \\
\text { feeding device form, and } \\
\text { selection for more hygienic } \\
\text { baby bottles }\end{array}$ \\
\hline
\end{tabular}

Since the publication of the groundbreaking compilation "The Adapted Mind" (Barkow et al. 1992), EP has emerged as a leading approach to the study of human psychology and behaviour (Laland and Brown 2011). Although much EP work related to reproductive strategies is focused on mating, including my own contributions to the field (Fessler et al. 2012; Kushnick 2013b), there are some classic works in EP related to the evolution of parenting behaviour (e.g., Daly and Wilson 1980, 1994) and-as illustrated by the range of contributions to this volume-it is a dynamic area within the field. More recent reviews of EP, including discussions of the strengths and limitations of the approach, have been written by Tooby and Cosmides (2005) and Confer et al. (2010).

\subsubsection{Example: Contraception and Reproductive Success}

As an example of the EP approach to technology and parenting, let us examine modern contraceptive technology and its effect on the production of offspring. Contraception consists of methods and devices that allow for the control of fertility. So, although birth control methods such as lactational infecundity and coitus interruptus have played a role in modern and most likely ancient human society, I will focus on devices. Modern contraceptive 
technologies range from mechanical (e.g., latex condoms) to medical (e.g., the 'pill') to a combination of the two (e.g., intrauterine devices, IUDs) (Speroff and Darney 2010). These technologies give their users unprecedented levels of assurance that sexual activity can occur with low risk of pregnancy. For example, IUDs provide their used a pregnancy rate of "between 1 and 3 per 100 woman-years" (Thonneau et al. 2006: 2612)..

Although modern technologies became available in the $20^{\text {th }}$ century, the history of contraceptive technology in the broadest sense goes back much further. McLaren (1990) provides a history of contraception with emphasis on methods used in Western culture from the classical civilizations onward. The ability and desire to lengthen birth intervals and limit family size likely goes back to the far reaches of prehistory (Cashdan 1985). The wide range of technologies used in small-scale societies suggests our ancestors might also have invented contraceptive technologies. Stanley (1993) provides a nice review of contraceptive technologies used in small-scale societies that includes, for example, vaginal plugs of seaweed used on Easter Island, various vegetal plugs used in African societies, and an opium plug used by Karo women in Indonesia.

Contraception is a technology that decouples our 'urge to have sex' with the reproductive consequences of that urge (Alexander 1988; Barkow and Burley 1980; Perusse 1993). It is part of the explanation for what has been called the 'central problem of human sociobiology' (Perusse 1993). The problem can be stated as follows: In most human societies and throughout human history, those who were culturally successful and controlled the most wealth were also the ones who had the most offspring. In post-demographic-transition societies, however, the relationship has flip-flopped. The most culturally successful individuals have the fewest offspring. From an EP perspective, this is a classic example of a modern environment (i.e., one where modern contraceptive technologies are easy to procure and use) interacting with evolved psychology (i.e., the 'urge' to copulate), resulting in maladaptive behaviour (i.e., lower than maximal reproductive success).

Of course, EP has no monopoly on our understanding of the relationship between contraceptive technology and parenting. Cultural evolution, and thus the DIT approach, also facilitates our understanding of the development and adoption of contraception, and its effects on fertility (Alvergne et al. 2011). Further, the use of contraceptive technologies, despite their effect in limiting reproductive success, may have a positive effect on maternal fitness (Ahmed et al. 2012), suggesting the HBE approach has something valuable to say on the subject. One possibility is that it signals an increase in selection on status-enhancement mechanisms over fertility-maximizing ones (Alvergne and Lummaa 2014).

\subsubsection{Example: Ultrasounds and Sex Selection in China}

The 'Missing Girls' of China are a somber example of how childrearing and technology interact from an EP perspective. Strong cultural preferences for sons, the introduction of a one-child policy in 1979 (see Figure 2, Panel B), and the increasing availability of sex-predetermination technology have contributed to this problem by making sex-selective abortion possible (Hesketh and Xing 2006). Figure 2 (Panel A) shows China's increasingly male-skewed sex ratio. The 'missing girls' problem is exacerbated after birth by higher female infant and child mortality rates.

Biased sex ratios and sex-biased parental investment have been observed in many species, including humans, and the reasons for the deviations from equity probably evolved to maximize ancestral parental fitness (West 2009). Brooks (2012) discusses the 'missing girls' problem from this perspective. Cronk (1993) discusses examples of evolved female preference, including one of relevance for the relationship between parenting and technologythe preference for daughters in post-industrial revolution America. Before industrialization, sons were likely preferred because of their value to rural, farming families. After industrialization, however, girls were likely a better investment because they were better able to get factory jobs.

Nonetheless, technologies such as ultrasound machines (like the one being used in Figure 1, Panel C-in Brazil rather than China in the illustration) that allow for the accurate determination of the sex of offspring before birth are evolutionarily novel. They only became available in China in 1979, but are now manufactured there and are, thus, quite plentiful. They provide a level of accuracy that traditional methods cannot match (cf. Peng and Huang 1999). Their contribution to the 'missing girls' problem is so important that the Chinese government sent a memo to all medical practitioners in 1989 warning against their use for prenatal sex determination, and then in 1994 legislation was passed to ban their use for this purpose. Unfortunately, their illicit use is still widely practiced (Junhong 2001; Kristof 1993). 
A.

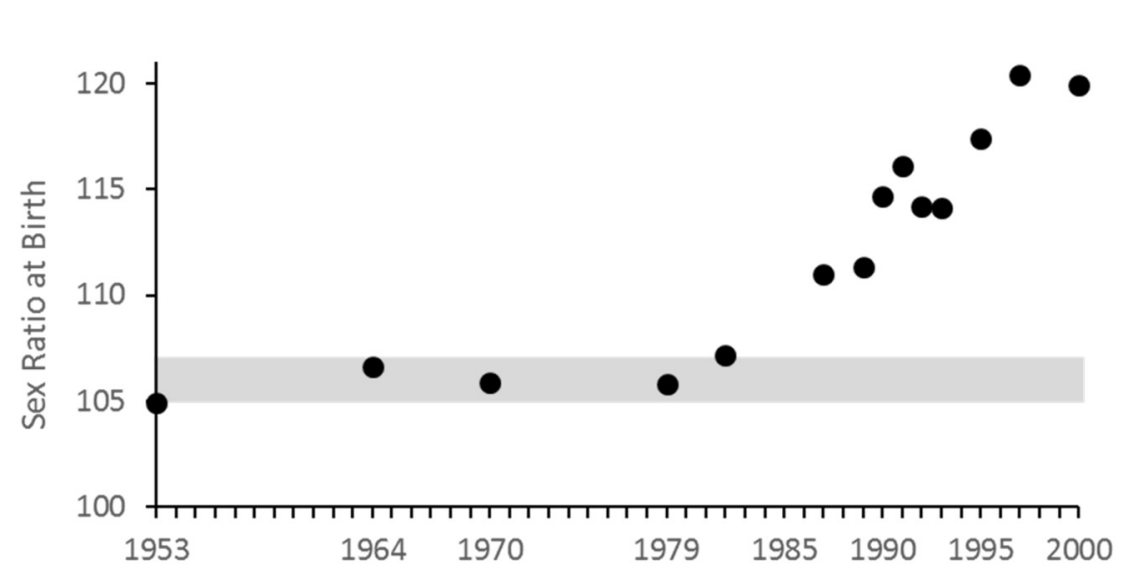

B.

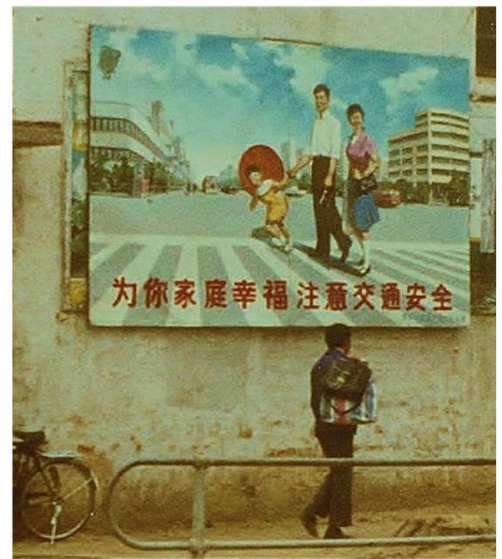

FIgURE 2. The "Missing Girls" of China: (a) sex ratio at birth (males per 100 females) in China from 1953 to 2000 (Bank 2006), where the gray bar is the 'normal' range for the rest of the world (Hesketh and Xing 2006); and, (b) one-child policy poster in China from 1982. Image copyright:: Robert Schediwy, Creative Commons Attribution-Share Alike 3.0 Unported License (https://commons.wikimedia.org/wiki/File:China_1982_happy_family_with_one_child.jpg).

The EP approach predicts that behaviour resulting from the use of such technology, because of its evolutionary novelty, will be maladaptive (i.e., reflecting the mismatch between the evolved brain and the current environment). Although abortions may reflect adaptive decision-making made by a well-adapted brain (Hill and Low 1992), some byproducts of sex-selective abortion on the scale of the experience in China include a severe marriage squeeze, and the potential for increased crime and mental illness (Brooks 2012; Hesketh and Xing 2006). Both phenomena might be considered maladaptive in the sense that they would lead to poorer reproductive and survival outcomes for children born into these environments.

In the future, we may see problems of this sort even in the absence of sex preferences. Artificial reproductive technologies such as in vitro fertilization of blastocysts can lead to an increased chance of bearing a son, while other methods can lead to an increased chance of bearing a daughter (Dean et al. 2010). Although they currently account for only 1 to 4\% of all babies born, their use is becoming increasingly common (Hardy and Maalouf 2017). If these methods are used as a means for sex-selection, as ultrasounds have, it could cause severe problems.

\subsection{Human Behavioural Ecology}

Human behavioural ecology (HBE) has as its focus behavioural strategies and attempts to explain these strategies as the product of naturally selected phenotypic responsiveness to salient aspects of the physical and social environment. The HBE approach is agnostic about the mechanisms generating behaviour (but appreciates that both genes and culture play a role). Nonetheless, the brain is viewed as a general-purpose tool that allows behaviour to quickly change in response to changing conditions. For these reasons, behaviour should be adaptive (i.e., leading to outcomes that maximize genetic contributions in future generations) even when the actor is situated in an evolutionarily novel environment. Technology changes the balance of fitness costs and benefits of various behaviour, and parents - who have evolved to be responsive to these sorts of factors-should adjust their behaviour in ways that maximize inclusive fitness. Practitioners of HBE assess this responsiveness by pitting human behaviour against the predictions of optimality models that specify the fitness-maximizing strategy under a set of explicit constraints. They often take the following generalized form "In context X, do $\alpha$; in context $\mathrm{Y}$, switch to $\beta^{\prime \prime}$ (Winterhalder and Smith 2000, p. 54).

Since the publication of the groundbreaking compilation "Evolutionary Biology and Human Social Behavior" (Chagnon and Irons 1979), HBE has emerged as an approach that attempts to balance sophisticated theoretical and empirical approaches (Laland and Brown 2011). Studies of parental behaviour, including my own contributions to the field (Kushnick 2009, 2010, 2102, 2013a, 2015), are a mainstay of the HBE approach (e.g., Lawson and Mace 2011; Voland 1998). More recent reviews of HBE, including discussions of the strengths and limitations of the approach have been written by Borgerhoff Mulder and Schacht (2012) and Nettle et al. (2013). 


\subsubsection{Example: Labour-Saving Technology and Women's Work}

The relationship between labour-saving technologies and women's work (and its effect on fertility) is a welldocumented example of an HBE approach to childbearing. Labour-saving technologies arose in the early to mid$20^{\text {th }}$ century in Western societies as a process described by Cowan (1976) as the "Industrial Revolution in the home," as well as more recently as development interventions in communities in the developing world (the second case is illustrated in Figure 1, Panel B). In both instances, their purpose was to increase the efficiency of housework. This efficiency has had diverse effects, including decreasing the amount of time spent on work, but paradoxically it has in some cases led to an increase in the amount of time spent on work (Cowan 1983; Strasser 1982; Thompson 1979). This is consistent with my own theoretical contribution to the helpers-at-the-nest literature (Kushnick 2012), where I showed that women can maximize fitness (operationalized as offspring survival) with increases, steady allocations, and decreases in the amount of direct parental care they provide to offspring when aided by helpers. At the root of this diversity of effects is that different sorts of help have different effects on the costs and benefits of care.

A number of HBE studies have shown the effects of labour-saving technologies on childbearing (see Table 2). Kramer and MacMillan (1998) argue that, among the Puuc Maya, labour-saving technologies (e.g., water pumps and grain mills) spare young girls from helping-related chores and thus lead to younger age at marriage. The researchers did not find a consistent effect on other fertility-related variables (Kramer and McMillan 1999). Among the Xculoc Maya, on the other hand, the researchers found a host of effects on fertility-related variables (Kramer and McMillan 2006). In Ethiopian Oromo communities, Gibson and colleagues found a wide range of effects of water taps-which transformed a multi-hour chore into a 30-minute one-on increasing fertility (Gibson and Lawson 2011; Gibson and Mace 2002a,b 2002b, 2006). They also found effects on childrearing, more specifically on infant mortality. The concomitant increase in fertility and decrease in mortality led to an increase in sibling competition for resources (a maladaptive consequence suggesting a role of EP in explaining these phenomena), and increased parental allocations offspring.

Bailey and Collins (2011) used econometric analysis to show that increases in household efficiency in the United States in the $20^{\text {th }}$ Century cannot account for the rise in mid-century fertility commonly referred to as the 'Baby Boom.' In fact, using state-level data from the same period, Lewis (2014) found that household technologies, such as electrification, had the effect of decreasing fertility, while at the same time increasing infant survival—especially in states most reliant on coal, as indoor air quality was increased the most drastically in these households.

TABLE 2. Human behavioural ecology studies of labour-saving technology interventions and their effect on childbearing and childrearing behaviour.

\begin{tabular}{|l|l|l|l|l|}
\hline Population & \multicolumn{2}{|c}{ Country } & Intervention & \multicolumn{2}{l}{ Effect } & \multicolumn{2}{l|}{ Reference(s) } \\
\hline Oromo & Ethiopia & Water taps & $\begin{array}{l}\text { Increased fertility; shorter first } \\
\text { birth intervals; lower infant } \\
\text { mortality; greater sibling } \\
\text { competition for resources; } \\
\text { increased parental investment in } \\
\text { offspring status }\end{array}$ & $\begin{array}{l}\text { Gibson \& Mace } \\
\text { 2002a,b, 2006; } \\
\text { Gibson \& Lawson } \\
2011\end{array}$ \\
\hline Puuc Maya & Mexico & $\begin{array}{l}\text { Water pumps } \\
\text { \& grain mills }\end{array}$ & $\begin{array}{l}\text { Less help provided to mothers; } \\
\text { lower age of first reproduction }\end{array}$ & $\begin{array}{l}\text { Kramer \& McMillan } \\
1998,1999\end{array}$ \\
\hline Xculoc Maya & Mexico & $\begin{array}{l}\text { Water pumps } \\
\text { \& grain mills }\end{array}$ & $\begin{array}{l}\text { Lower age of 1st reproduction; } \\
\text { higher annual probability of birth; } \\
\text { larger completed family }\end{array}$ & $\begin{array}{l}\text { Kramer \& McMillan } \\
2006\end{array}$ \\
\hline
\end{tabular}




\subsubsection{Example: Infant-Carrying Devices and Subsistence}

Infant-carrying devices exemplify the human behavioural ecology approach to the effects of technology on childrearing. Just as baby-carriers and strollers (or prams) are among the best-selling pieces of baby-care equipment among parents in Western societies, devices with similar functions are used in various forms and to various extents in small-scale societies, as well. Infant-carrying devices in small-scale societies range from slings or pouches, baskets, to rigid cradleboards. An example of this style of technology is the Komse, used by Sami reindeer herders of north Europe. Illustrated in Figure 1 (Panel F) and described by Skold et al. (2011) as "a small wooden boat box where infants are kept almost constantly for 1 or even 2 years." Another well-known example is the papoose, a generalized term (though the word is borrowed from Algonquian and actually means 'baby') used to refer to the cradleboard infant-carrying devices used by a variety of Native American groups.

Although one might expect these sorts of technologies simply to be the product of cultural processes, passed on from generation to generation or borrowed from inventive neighbours, there is evidence that the type of infantcarrying technology used by a given society is shaped by the environment. In his cross-cultural study of the type of device used, Whiting (1981) found that slings were more likely to be used in hot environments, cradles in cold ones. His account, thus, emphasized the thermoregulatory function of this technology, while discounting the importance of subsistence strategy (Konner 2005). Subsistence, however, may still play a role in shaping the costs and benefits of using an infant-carrying device.

Whether any sort of carrier is used might be shaped by another selective pressure: whether women play a significant role in subsistence activities. When they do, infant-carrying technology may arise to fulfil the dual needs of bringing the baby along to wherever that work must be done, and keeping the woman's hands free to engage in said work. The Standard Cross-Cultural Sample (Murdock and White 1969)—a cross-cultural dataset akin to the ones used by Whiting (1981) in the study discussed above-provides the means for a simple test of this hypothesis ${ }^{2}$. As shown in Figure 2, where women have a relatively smaller role in subsistence activity, they are less likely to have infant-carrying technology compared to societies where women have a relatively larger role in subsistence. Such an effect is consistent with observations I have made among the Karo people of North Sumatra, Indonesia. Pictured in Figure 1 (Panel D) is one woman's ingenious method for taking care of her child while working her tomato garden.

So important are these sorts of technologies to the ability of women to engage in other activities that marketing scholars are investigating their effect on consumption in industrialized societies (Hansson 2015). In addition to the cost-benefit approach of HBE, the DIT approach might be a useful framework for investigating infantcarrying technologies as their form is likely also, as discussed above, the product of cultural evolutionary processes.

\subsection{Dual Inheritance Theory}

Dual inheritance theory (DIT) has as its focus cultural evolution, which it attempts to explain as the product of evolutionary forces analogous to those in biological evolution (e.g., natural selection, drift) and other unique ones (e.g., biased transmission). The brain is viewed as tool, with both general and specific elements, that provides humans with a capacity for culture. Via cultural evolution, humans can adapt to changing environments more quickly than they can via biological evolution, but also culture can be rigid and inflexible. DIT, thus, views human adaptiveness to current environments as intermediate between that posited by EP and HBE—and the degree of adaptiveness is determined by how and from whom culture is transmitted. Parental transmission often leads to adaptive outcomes; transmission from nonrelatives, especially those with power, and fads and fashions can lead

\footnotetext{
2 The test uses two variables from the Standard Cross-Cultural Sample (SCCS: Murdock and White 1969). The first variable is a recode of Variable 28: Infant Carrying Device (Barry and Paxson 1971). The absence of infant carrying technology included those coded as "none, skin contact" (original code 1) and "none, clothing or blanket" (original code 2). The presence of infant carrying technology included those coded as "sling or pouch" (original code 3), "basket" (original code 4), or "rigid cradle board" (original code 5). The variable is a recode of Variable 586: Relative Time and Effort Expended on Subsistence Activities (Whyte 1978). Women having a relatively smaller role included those coded as "men clearly expend more" (original code 1). Women having a relatively larger role included those coded as "men and women roughly equal" (original code 2) and "women clearly expend more" (original code 3). Societies were excluded when data were missing for either variable, leaving a sample of 77 societies of the 186 total in the SCCS.
} 

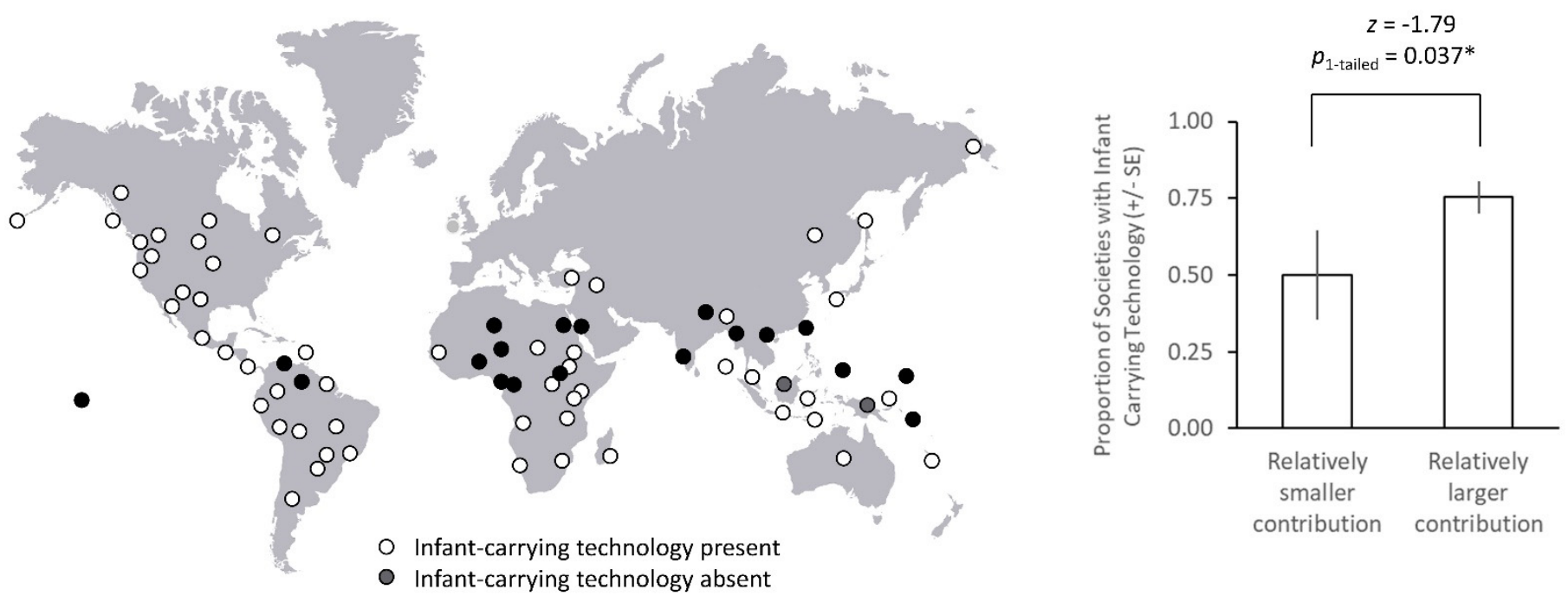

FIGURE 3. Societies are more likely to have and make use of infant-carrying devices when women play a relatively larger role in subsistence activities. Comparison based on 77 societies from the Standard CrossCultural Sample (Murdock and White 1969).

to maladaptive or adaptively neutral outcomes. Cultural evolution may lead to the development of increasingly refined technologies related to parenting, but also it might lead to maladaptive forms under certain conditions.

Since the publication of the groundbreaking monograph "Cultural Transmission and Evolution" (Cavalli-Sforza and Feldman 1981), DIT has emerged as a quantitatively rigourous of the approache, with a mathematical sophistication akin to population genetics (Laland and Brown 2011). Although I have made some contributions to the cultural evolution literature (e.g., Kushnick et al. 2014), none of it has focused on parenting behaviour. Studies of parenting behaviour in DIT are by-and-large focused on the effect of culture on reproductive behaviour (e.g., Newson et al. 2007). More recent reviews, including discussions of its transition from a mostly theoretical approach to one that balances theory and empirical hypothesis testing, have been written by Boyd et al. (2011) and Mesoudi et al. (2016).

\subsubsection{Example: Telenovelas and Fertility}

Serial broadcasts over television and radio are an apt example of how technology can affect reproductive behavior. Scholars adopting the DIT approach have long recognized the effect of cultural inheritance on fertility (e.g., Boyd and Richerson 1985), in particular how cultural evolutionary mechanisms could lead to lower fertility than that which maximizes fitness (e.g., Borgerhoff Mulder 1998; Newson et al. 2005; Newson et al. 2007; Shenk 2009). In a recent review, Colleran (2016) outlines a number of cultural evolutionary models of fertility decline and highlights some areas of overlap with other approaches. For one of the models, she discusses how prestige-bias in cultural transmission (DIT approach) and adaptive prestige-seeking (HBE approach) that leads to low fertility as a byproduct are hard to distinguish.

Since the Sabido productions of 1970s and 80s Mexico, serial broadcasts (i.e., soap operas) over TV and radio have been used as a mechanism for transmitting information about family-planning and other social issues in developing countries (PMC 2009). Table 2 provides an overview of the soap operas reviewed by Basten (2010). In those whose method is listed as explicit, the production carried overt messages about the merits of small families and was funded and often co-produced by governmental and non-governmental agencies. In those whose method is listed as implicit, the message was inadvertent. In almost all of the cases, there is evidence that the production led to changes in norms and behaviour related to childbearing. For instance, the family planning wing of the Mexican government received a 500\% increase in phone calls, with many reporting the soap operas as the reason for calling. Further, contraceptives sales saw a three-fold increase (Basten 2010). 
TABLE 3. Soap operas with family planning messages (reviewed in Basten 2010).

\begin{tabular}{|l|l|l|l|l|l|}
\hline Program(s) & Country & Span & Media & Method & Reference(s) \\
\hline $\begin{array}{l}\text { Acompaname (Accompany Me), } \\
\text { Vamos Juntos (We Go Together), } \\
\begin{array}{l}\text { Caminemos (Let's Walk), Nosotros la } \\
\text { Mujeres (We the Women), Por Amor } \\
\text { (For Love) }\end{array}\end{array}$ & Mexico & 1970 s-80s & TV & Explicit & PMC 2009 \\
\hline Bayt al-'a'ila (The Family House) & $\begin{array}{l}\text { Morrocco, } \\
\text { Egypt, } \\
\text { Lebanon }\end{array}$ & $1993-94$ & TV & Explicit & Elkamel 1998 \\
\hline Apwe Pleri (After the Pleasure) & St Lucia & $1996-98$ & Radio & Explicit & Vaughn et al. 2000 \\
\hline $\begin{array}{l}\text { Twende na Wakati (Let's Go With } \\
\text { The Times) }\end{array}$ & Tanzania & $1995-97$ & Radio & Explicit & Rogers et al. 1999 \\
\hline Hum Log (People Like Us) & India & $1984-85$ & TV & Implicit & Singhal et al. 1988 \\
\hline Various Rede Globo telenovelos & Brazil & $1960-2000$ & TV & Implicit & La Ferrara et al. 2012 A \\
\hline
\end{tabular}

A The Basten (2010) review cited a pre-publication version of the La Ferrara et al. 2012 paper.

The most well-studied example with the most convincing evidence for a childbearing effect caused by the serial broadcasts are the Rede Globo telenovelas, limited-run soap operas, from Brazil (La Ferrara et al. 2012). Brazil is noteworthy because the halving of average family sizes between 1970 and 1990 happened in the absence of government intervention, in an environment in which advertisement of contraception was illegal. While this was occurring, the number of women receiving the Globo network to their homes doubled. Content analysis of 115 Globo telenovelas found that over $90 \%$ of the main female characters age 50 or lower had 1 or no children. Leveraging data on community differences in the timing of access to the network, La Ferrara et al. (2012) found that this access was a significant predictor of reductions in childbearing. Further, they argue that the telenovelas had a causal relationship with childbearing by showing that child naming patterns were also influenced by the timing of access to the Globo telenovelas. Interesting from an evolutionary perspective is the additional observation that viewers were copying telenovela characters that they identified as having prestige.

Although I have emphasized the role of the DIT approach for this example, there are areas of overlap with the other approaches. For instance, as discussed in the contraception example earlier, lower fertility (and thus reproductive output) can be analyzed from an EP perspective. Further, in some studies of the effect of electrification, which could be considered a labour-saving technology, changes in childbearing behaviour are chalked up to the effects of television (e.g., Grimm et al. 2015; Peters and Vance 2011), which might be best understood from the DIT perspective.

\subsubsection{Example: Evolution of Baby Bottles}

Humans have long found ways to artificially feed infants when the mother is unable, unwilling, or not allowed to do so herself (Hrdy 1992, 2000; Wickes 1953a). These methods range from the recruitment of wet nurses to the use of feeding devices, such as baby bottles. Bottles have been used to deliver human or animal milk, and sometimes various water or milk-based cereal mixtures (such as pap and panada) used in Western cultures (Stevens et al. 2009; Tenner 2003; Weinberg 1993; Wickes 1953b) and the wide range of supplementary foods used in smallscale societies (Sellen 2001). I will focus here on baby bottles, as they illustrate how a technology related to childrearing changed over time via a process natural selection on cultural variants—one of the evolutionary forces that can drive cultural evolution (Henrich and McElreath 2003). 
The archaeological evidence for baby bottles goes back only to the $4^{\text {th }}$ century BC. In 2012, archaeologists unearthed a 2400-year old Messapian infant-feeding vessel shaped like a pig that, coincidentally, doubled as a baby rattle (Budin and Turfa 2016). The bottle, like others found from this period, was made from terracotta (i.e., fired clay) (Stevens et al. 2009; Wickes 1953b). Figure 1, Panel A provides an example of this type of technology. These early bottles were once thought to be oil vessels, but chemical analysis revealed that they held milk. Bottles from the middle ages were fashioned from cow horns with punctured tips. From the $17^{\text {th }}$ century forward, they were made from a variety of materials, including wood, pewter, silver, and ceramic. Feeding devices used during from the $16^{\text {th }}$ to $18^{\text {th }}$ centuries were rather unhygienic. In the $19^{\text {th }}$ century, glass bottles, which were ostensibly easier to clean, were introduced. Still, though, hygiene was problematic. In the early $19^{\text {th }}$ century, one-third of all artificiallyfed children died before their first birthday (Stevens et al. 2009).

In 1845, the first Indian rubber nipples were used (Weinberg 1993). Another innovation in infant-feeding devices during this period was the banjo-shaped bottle with a long siphon tube that allowed babies to feed themselves. Unfortunately, they were almost impossible to keep bacteria-free. They were eventually abandoned and even outlawed some places, earning them the moniker 'murder bottles' (American Association of Pediatricians 2017). Figure 4 shows the difference in death rates between breast- and bottle-fed infants in Paris in 1898. As the $20^{\text {th }}$ century progressed, heat-resistant glass bottles were replaced by plastic ones, and the nipples replaced with more hygienic ones (Tenner 2003). Essentially, changes in bottle shape and material were driven by a process of cultural evolution by natural selection. Over time, bottles became more efficient and more hygienic.

Other evolutionary approaches might also be useful for looking at this phenomenon. Infant bottle-feeding, especially the debate over which is best—breast or bottle- has been heavily influenced by marketing forces in the $20^{\text {th }}$ century, especially in developing countries where infant mortality is still high. For that reason, it would be interesting to analyze it from a DIT perspective. Other technologies might be interesting to look at from an EP point of view. For instance, the baby cage illustrated in Figure 1 (Panel B) could be thought of as a potentially maladaptive solution to an evolutionarily novel problem - getting fresh air for your child in the high-rises of the modern city.

\section{CONCLUSION}

In this chapter, I have used Smith's (2000) 'three styles' framework to explore, from an evolutionary perspective, the many ways that parenting and technology interact. For each of the evolutionary approaches, I briefly discussed two examples of this relationship, one related to childbearing and the other related to childrearing. Now, I would like to bring the exploration full circle, and reflect on the question posed in the introduction: Is the evolutionary approach a useful one to understand this relationship? My feeling is that the answer is a resounding yes.

First, although each has as its focus the application of evolutionary theory to the study of human behaviour, each of the three styles brings a different set of assumptions and priorities. To illustrate each, I chose examples that I felt exemplified what that approach brings to the table, but while doing so it was clear that for many of the examples more than one of the approaches had something to say. At the start of the chapter, I used the example of infant-centered television, which rose to popularity due to the efforts of marketing companies who convinced parents that the shows could boost their children's intelligence (which can be understood from the DIT perspective) and it allows parents to 'park' their children, freeing them for other activities (which can be understood from the HBE perspective). Of course, there are maladaptive consequences of TV watching in children (Braithwaite et al. 2013) (which can be understood from the EP perspective).

Second, an evolutionary perspective points our investigations to specific, and theoretically justified, behavioural concomitants of technological change. Such is the case with subsistence change, for example with the transition from forager to agriculturalist. Although there certainly will be changes in technological features of those societies - it takes different tools to hunt and to gather than it does to cultivate-changes in parenting behavior may be due to the other changes in society as a whole (such as social structure and property rights, for example) rather than to the technology change per se. The example of infant-carrying technology and subsistence explored earlier is a case in point. Whereas Whiting (1981) discounted subsistence as a driver of parenting behaviour (i.e., the use of infant-carrying devices), the simple cross-cultural test of one aspect of subsistence (i.e., the amount of subsistence work done by women versus men) supported the existence of a relationship between the two. Draper and Cashdan (1988) present a good example of approaching this sort of comparison in a piecemeal fashion because evolutionary theory guided the behaviour they predicted would change with subsistence change. 


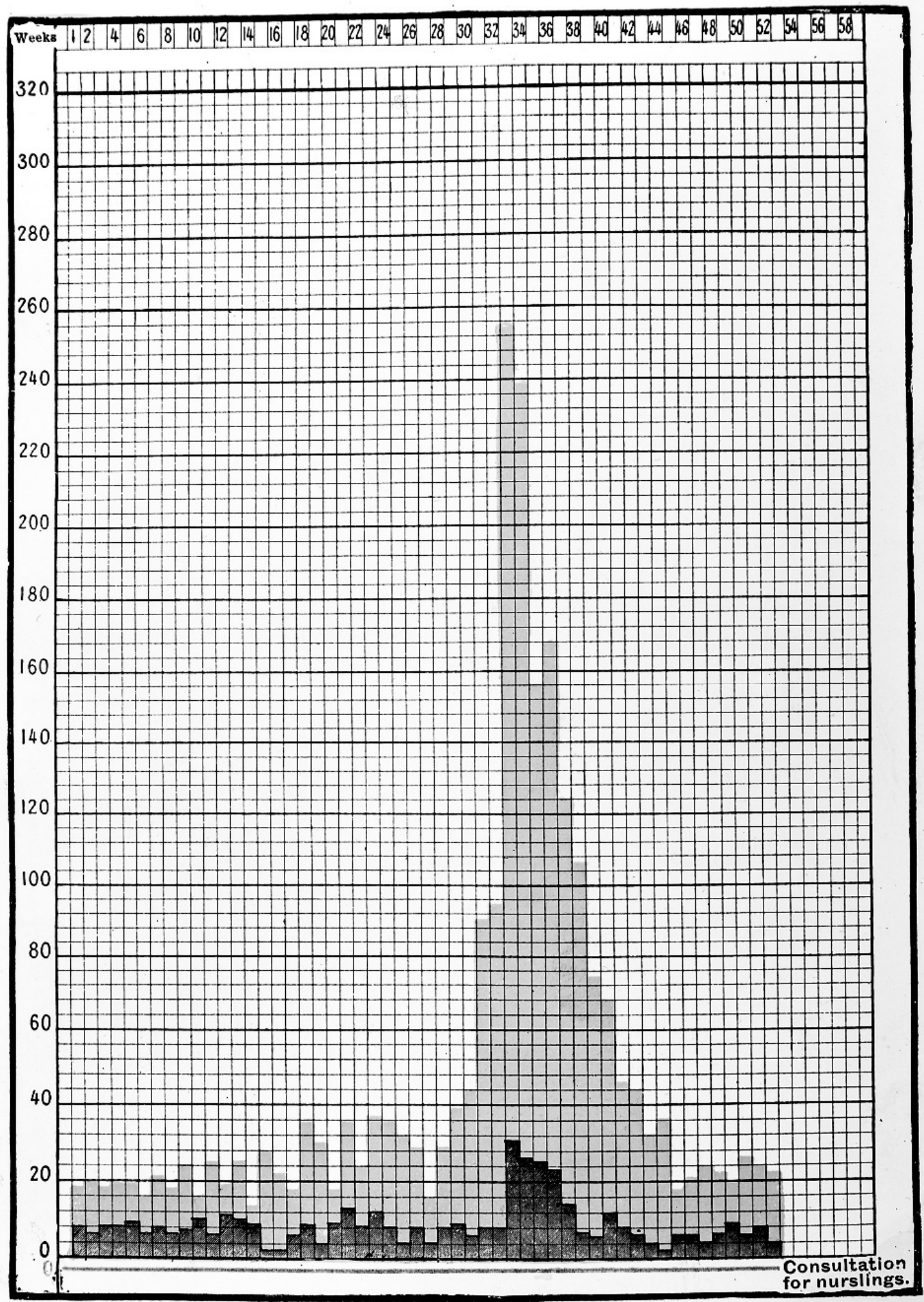

FIG. 121.-Death-rate from diarrhoa among infants under one year of age in Paris during the year 1898 . Black=breast-fed; red = bottle-fed. 'The horizontal blue line at zero shows that the mortality was nil at the Consultation in 1898 .

FIGURE 4. Difference in mortality rates (deaths per 1000 from diarrhea) by week of the first year of life in Paris in 1898. The black bars are breast-fed infants; the gray bars are bottle-fed infants. Copyright information for image: Wellcome Library, London; Creative Commons Attribution 4.0 International License. (Source:

https://commons.wikimedia.org/wiki/File:Graph_showing_deaths_in_breast_and_bottle_fed_children,_1898_ Wellcome_M0018551.jpg) 
There are other examples of this benefit of the evolutionary approach. In my own research on maternal investment strategies in a handful of small-scale and industrialized societies, I found that technological indicators of the caretaking environment were good predictors of strategy (Kushnick et al. 2015). For example, almost 79\% of the variance in the degree to which a mother's age (a factor influencing the cost of care) influenced her caretaking strategy was explained by her nation's oil use per capita in a cross-cultural study of 4 small-scale and 3 industrialized societies (adjusted $R^{2}=0.787$ ). I tested for this relationship in the first place because the evolutionary approach suggested it. That is, increasing industrialization is indicative of an environment where it is beneficial to invest in one's own embodied capital at younger ages, leaving the bulk of investment in parental effort to older ages (Kaplan 1996; Kaplan et al. 2003).

In exploring the relationship between parenting and technology, one is necessarily looking the future. Technological advances progress in an exponential fashion, and we are in the zone of acceleration. Can the evolutionary approaches discussed in this chapter help us to forecast the sorts of technologies related to parenting that we might interact with in the future? The evolutionary approach advanced in this chapter provides no 'crystal ball' but it does provide a means for making predictions about how we might interact with various types of technology. The relationship between parenting and technology is a multifaceted one. This relationship, in the future as in the past and present, is one that may be shaped by the residues of our evolutionary past, our ability to adapt phenotypically to changing environments that modify the costs and benefits of care, and/or the whims of fads and fashions. All these things are possible —and all these things are consistent with an evolutionary approach to understanding human behaviour.

\section{REFERENCES CITED}

Ahmed S, Li Q, Liu L, and Tsui AO. 2012. Maternal deaths averted by contraceptive use: an analysis of 172 countries. The Lancet 380(9837):111-125.

Alexander RD. 1988. Evolution and human behavior: What does the future hold? In: Betzig L, Borgerhoff Mulder M, and Turke P, editors. Human reproductive behavior: a Darwinian perspective. New York: Cambridge University Press. p 317-341.

Alvergne A, Gibson MA, Gurmu E, and Mace R. 2011. Social transmission and the spread of modern contraception in rural Ethiopia. PLoS ONE 6(7):e22515.

Alvergne A, and Lummaa V. 2014. Ecological variation in wealth-fertility relationships in Mongolia: the 'central theoretical problem of sociobiology' not a problem after all? Proceedings of the Royal Society B: Biological Sciences 281:20141733.

American Association of Pediatricians. 2017. Pediatric History Center: Stories from the vault. https://www.aap.org/en-us/about-the-aap/PediatricHistory-Center/Pages/Stories-From-The-Vault.aspx (accessed on 1 July 2017).

Bailey MJ, and Collins WJ. 2011. Did improvements in household technology cause the Baby Boom? Evidence from electrification, appliance diffusion, and the Amish. American Economic Journal: Macroeconomics 3:189-217.

Bank W. 2006. China: Research report on gender gaps and poverty reduction. Washington, DC: World Bank.

Barkow JH, and Burley N. 1980. Human fertility, evolutionary biology, and the demographic transition. Ethology and Sociobiology 1(2):163-180.
Barkow JH, Cosmides L, and Tooby J, editors. 1992. The adapted mind: Evolutionary psychology and the generation of culture. New York: Oxford University Press.

Barry H, Paxson LM. 1971. Infancy and early childhood: cross-cultural codes 2. Ethnology 10:466-508.

Basten S. 2010. Television and fertility. Finnish Yearbook of Population Research XLV:67-82.

Blurton Jones NG. 1990. Three sensible paradigms for research on evolution and human behavior. Ethology and Sociobiology 11:353-359.

Borgerhoff Mulder M. 1998. The demographic transition: Are we any closer to an evolutionary explanation? Trends in Ecology and Evolution 13(7):266-270.

Borgerhoff Mulder M, and Schacht R. 2012. Human behavioral ecology. In: Encyclopedia of the Life Sciences. Chichester: John Wiley \& Sons, Ltd. p 1-10.

Boyd R, and Richerson P. 1985. Culture and the evolutionary process. Chicago: University of Chicago.

Boyd R, Richerson P, and Henrich J. 2011. The cultural niche: why social learning is essential for human adaptation. Proceedings of the National Academy of Science USA 108:10918-10925.

Braithwaite I, Stewart AW, Hancox RJ, Beasley R, Murphy R, Mitchell EA, and the IPTSG. 2013. The Worldwide Association between Television Viewing and Obesity in Children and Adolescents: Cross Sectional Study. PLOS ONE 8(9):e74263.

Brooks R. 2012. “Asia's Missing Women” as a Problem in Applied Evolutionary Psychology? Evolutionary Psychology 12(5):910-925.

Budin S, and Turfa J, eds. 2016. Women in antiquity: Real women across the ancient world. NY: Routledge. 
Cashdan E. 1985. Natural fertility, birth spacing, and the "first demographic transition". American Anthropologist $87: 651-653$

Cavalli-Sforza LL, and Feldman M. 1981. Cultural transmission and evolution: A quantitative approach. Princeton, NJ: Princeton University Press.

Chagnon N, and Irons W, editors. 1979. Evolutionary biology and human social behavior. North Scituate, MA: Duxbury.

Christakis DA. 2009. The effects of infant media usage: what do we know and what should we learn? Acta Padiatrica 98(1):8-16.

Colleran H. 2016. The cultural evolution of fertility decline. Philosophical Transactions of the Royal Society B: Biological Sciences 371(1692):20150152.

Confer JC, Easton JA, Fleischman DS, Goetz CD, Lewis DM, Perilloux C, and Buss DM. 2010. Evolutionary psychology. Controversies, questions, prospects, and limitations. Am Psychol 65(2):110-126.

Cowan RS. 1976. The 'industrial revolution' in the home: Household technology and social change in the $20^{\text {th }}$ century. Technology and Culture 17: 1-23.

Cowan RS. 1983. More work for mother: The ironies of household technology from the open hearth to the microwave. New York: Basic Books.

Cronk L. 1993. Parental favoritism toward daughters. American Scientist 81:272-279.

Daly M, and Wilson M. 1980. Discriminative parental solicitude: a biological perspective. Journal of Marriage and the Family 42(2):277-288.

Daly M, and Wilson M. 1994. The psychology of parenting in evolutionary perspective and the case of human filicide. In: Infanticide and parental care. Switzerland: Harwood Academic. p 73-104.

Daly M, and Wilson ML. 1999. Human evolutionary psychology and animal behaviour. Animal Behaviour 57:509-519.

Dean J, Chapman M, and Sullivan E. 2010. The effect on human sex ratio at birth by assisted reproductive technology (ART) procedures - an assessment of babies born following single embryo transfers, Australia and New Zealand, 2002-2006. BJOG: An International Journal of Obstetrics \& Gynaecology 117:16281634.

Draper P, and Cashdan E. 1988. Technological change and child behavior among the !Kung. Ethnology 27(4):339365.

Elkamel FM. 1998. Soap operas may be good for health: Impact evaluation of the Egyptian soap opera, 'Family House'. La Revue de Santé de la Méditerranée Orientale 41:178-180.

Fessler DMT, Stieger S, Asaridou SS, Bahia U, Cravalho M, de Barros P, Delgado T, Fisher ML, Frederick D, Geraldo Perez P et al. . 2012. Testing a postulated case of intersexual selection in humans: The role of foot size in judgments of physical attractiveness and age. Evolution and Human Behavior 33:147-164.
Fischer L. 1905. The health-care of the baby. NY: Funk \& Wagnalls.

Gibson MA, and Lawson DW. 2011. "Modernization" increases parental investment and sibling resource competition: evidence from a rural development initiative in Ethiopia. Evolution and Human Behavior 32(2):97-105.

Gibson MA, and Mace R. 2002a. The impact of laborsaving technology on first birth intervals in rural ethiopia. Human Biology 74:111-128.

Gibson MA, and Mace R. 2002b. Labor-saving technology and fertility increase in rural africa. Current Anthropology 43(4):631-637.

Gibson MA, and Mace R. 2006. An energy-saving development initiative increases birth rate and childhood malnutrition in rural Ethiopia. PLOS Medicine 3(4):e87.

Grimm M, Sparrow R, and Tasciotti L. 2015. Does electrification spur the fertility transition? Evidence from Indonesia. Demography 52(5):1773-1796.

Hansson N. 2015. "Mobility-things" and consumption: conceptualizing differently mobile families on the move with recent purchases in urban space. Consumption Markets \& Culture 18:72-91.

Hardy ICW, and Maalouf WE. 2017. Partially constrained sex allocation and the indirect effects of assisted reproductive technologies on the human sex ratio. Journal of Biosocial Science 49:281-291.

Henrich J, and McElreath R. 2003. The evolution of cultural evolution. Evolutionary Anthropology 12:123-135.

Hesketh T, and Xing ZW. 2006. Abnormal sex ratios in human populations: Causes and consequences. Proceedings of the National Academy of Sciences 103(36):13271-13275.

Hill E, and Low BS. 1992. Contemporary abortion patterns: A life history approach. Ethology and Sociobiology 13(1): 35-47.

Hrdy SB. 1992. Fitness tradeoffs in the history and evolution of delegated mothering with special reference to wet-nursing, abandonment, and infanticide. Ethology and Sociobiology 13:409-442.

Hrdy SB. 2000. Mother nature: Maternal instincts and how they shape our species. NY: Ballantine.

Junhong C. 2001. Prenatal sex determination and sexselective abortion in rural Central China. Population and Development Review 27(2):259-281.

Kaplan HS. 1996. A theory of fertility and parental investment in traditional and modern human societies. Yearbook of Physical Anthropology 39:91-135.

Kaplan HS, Lancaster JB, and Robson A. 2003. Embodied capital and evolutionary economics of the human life span. In: Carey JR, and Tuljapurkar S, editors. Life span: evolutionary, ecological, and demographic perspectives. New York: Population Council. p 152-182. 
Konner M. 2005. Hunter-gatherer infancy and childhood: The !Kung and others. In: Hewlett BS, and Lamb ME, editors. Hunter-gatherer childhoods: Evolutionary, developmental, and cultural perspectives. NY: Transaction. $\mathrm{p}$ 19-64.

Kramer KL, and McMillan GP. 1998. How maya women respond to changing technology. Human Nature 9(2):205-223.

Kramer KL, and McMillan GP. 1999. Women's labor, fertility, and the introduction of modern technology in a rural Maya village. Journal of Anthropological Research 55:499-520.

Kramer KL, and McMillan GP. 2006. The effect of laborsaving technology on longitudinal fertility changes. Current Anthropology 47(1):165-172.

Kristof ND. 1993. China: ultrasound abuse in sex selection. Womens Health Journal 4:16-17.

Kushnick G. 2009. Parental supply and offspring demand amongst Karo Batak mothers and children. Journal of Biosocial Science 14(2):183-193.

Kushnick G. 2010. Resource competition and reproduction in Karo Batak villages. Human Nature 21(1):62-81.

Kushnick G. 2012. Helper effects on breeder allocations to direct care. American Journal of Human Biology 24:545550 .

Kushnick G. 2013a. Access to resources shapes maternal decision-making: Evidence from a factorial vignette experiment. PLOS ONE 8(9):e75539.

Kushnick G. 2013b. Why do the Karo Batak prefer women with big feet? Flexible mate preferences and the notion that one size fits all. Human Nature 24(3):268-279.

Kushnick G, Gray RD, and Jordan FM. 2014. The sequential evolution of land tenure norms. Evolution and Human Behavior 35(4):309-318.

Kushnick G, Hanowell B, Kim J-H, Langstieh B, Magnano V, and Oláh K. 2015. Experimental evidence for convergent evolution of maternal care heuristics in industrialized and small-scale populations. Royal Society Open Science 2:140518.

La Ferrara E, Chong A, and Duryea S. 2012. Soap operas and fertility: Evidence from Brazil. American Economic Journal: Applied Economics 4(4):1-31.

Laland KN, and Brown GR. 2011. Sense and nonsense: Evolutionary perspectives on human behaviour (2nd edition). New York: Oxford University Press.

Lawson DW, and Mace R. 2011. Parental investment and the optimization of human family size. Philosophical Transactions of the Royal Society B: Biological Sciences 366:333-343.

Lewis J. 2014. The impact of technological change within the home. Toronto: University of Toronto.

McLaren A. 1990. A bistory of contraception: From antiquity to the present day. Oxford: Basil Blackwell.
Mesoudi A, Chang L, Dall SRX, and Thornton A. 2016. The evolution of individual and cultural variation in social learning. Trends in Ecology \& Evolution 31(3):215225.

Murdock GP, and White DR. 1969. Standard CrossCultural Sample. Ethnology 9:329-369.

Nettle D, Gibson MA, Lawson DW, and Sear R. 2013. Human behavioral ecology: current research and future prospects. Behavioral Ecology 24(5):1031-1040.

Newson L, Postmes T, Lea SEG, and Webley P. 2005. Why are modern families small? Toward an evolutionary and cultural explanation for the demographic transition. Personality and Social Psychology Review 9(4):360-375.

Newson L, Postmes T, Lea SEG, Webley P, Richerson PJ, and McElreath R. 2007. Influences on communication about reproduction: the cultural evolution of low fertility. Evolution and Human Behavior 28(3):199-210.

Oxford Living Dictionary. 2017. Technology. Oxford Living Dictionary. Oxford University Press. https://en.oxforddictionaries.com/definition/technol ogy (Accessed on 25 June 2017).

Peng X, and Huang J. 1999. Chinese traditional medicine and abnormal sex ratio at birth in China. Journal of Biosocial Science 31:487-503.

Perusse D. 1993. Cultural and reproductive success in industrial societies: testing the relationship at the proximate and ultimate levels. Behavioral and Brain Sciences 16:267-322.

Peters J, and Vance C. 2011. Rural electrification and fertility - Evidence from Côte d'Ivoire. The Journal of Development Studies 47(5):753-766.

PMC. 2009. Sabido methodology. http://www.populationmedia.org/our-approach (accessed 15 June 2017).

Rogers EM, Vaughan PW, Swalele RM, Rao N, Svenkerud P, and Sood S. 1999. Effects of an entertainmenteducation radio soap opera on family planning behavior in Tanzania. Studies in Family Planning 30:193211.

Sellen, D. 2001. The relationship between subsistence and age at weaning in 'preindustrial' societies. Human Nature 12(1):47-87.

Shenk MK. 2009. Testing three evolutionary models of the demographic transition: Patterns of fertility and age at marriage in urban South India. American Journal of Human Biology 21:501-511.

Singhal A, Rogers EM, and Cozzens MD. 1988. Effects of "Hum Log," a television soap opera, on women's status and fertility in India. 39th Annual Conference of the International Communication Association. San Francisco.

Sköld P, Axelsson P, Karlsson L, and Smith L. 2011. Infant mortality of Sami and settlers in Northern Sweden: the era of colonization 1750-1900. Global Health Action 4(1):8441. 
Smith EA. 2000. Three styles in the evolutionary analysis of human behavior. In: Lee Cronk NC, and W. Irons, editor. Human behavior and adaptation: an anthropological perspective. Hawthorne, NY: Aldine de Gruyter. p 2746.

Speroff L, and Darney PD. 2010. A clinical guide for contraception $\left(5^{\text {th }}\right.$ edition). Philadelphia, PA: Lippincott, Williams, \& Wilkins.

Stanley A. 1993. Mothers and daughters of invention: Notes for a revised history of technology. Metuchen, NJ: The Scarecrow Press, Inc.

Stevens EE, Patrick TE, and Pickler R. 2009. A history of infant feeding. The Journal of Perinatal Education 18(2):32-39.

Strasser S. 1982. Never done: A bistory of American housework. New York: Pantheon Books.

Tenner E. 2003. Our own devices: How technology remakes bumanity. New York: Vintage Books.

Thompson J. 1979. Housework \& technological change. Australian Left Review 69:9-19.

Thonneau P, Almont T, de la Rochebrochard E, Maria B, 2006. Risk factors for IUD failure: results of a large multicentre case-control study. Human Reproduction 21:2612-16.

Tooby J, and Cosmides L. 2005. Conceptual foundations of evolutionary psychology. In: Buss DM, editor. The bandbook of evolutionary psychology. Hoboken, NJ: Wiley. p 5-67.
Vaughn PW, Regis A, and St. Catherine E. 2000. Effects of an entertainment-education radio soap opera on family planning and HIV prevention in St. Lucia. International Family Planning Perspectives 26:148-157.

Voland E. 1998. Evolutionary ecology of human reproduction. Annual Review of Anthropology 27:347-374.

Weinberg F. 1993. Infant feeding through the ages. Canadian Family Physician 39:2016-2020.

West SA. 2009. Sex allocation. Princeton, NJ: Princeton University Press.

White, L. 1959. The evolution of culture: The development of civilization and the fall of Rome. Berkeley: University of California Press.

Whiting JWM. 1981. Environmental constraints on infant care practices. In: Munroe, R., et a., editor. Handbook of Cross-Cultural Human Development. New York: Garland. p 155-179.

Whyte M. 1978. The relative status of women. Ethnology 17:211-37.

Wickes IG. 1953a. A history of infant feeding: part I. Primitive peoples: Ancient works: Renaissance writers. Archives of Disease in Childhood 28(138):151-158.

Wickes IG. 1953b. A history of infant feeding: part IV. Nineteenth century continued. Archives of Disease in Childhood 28(141):416-422.

Winterhalder B, Smith EA. 2000. Analyzing adaptive strategies: Human behavioral ecology at 25 . Evolutionary Anthropology 9: 51-72. 